\title{
BARBARA ŚNIEŻEK
}

INSTYTUT SZTUKI, POLSKA AKADEMIA NAUK

\section{PIOSENKA RELIGIJNA NA FESTIWALU SACROSONG W LATACH I969-1978}

$\mathrm{P}$ rzyglądając się współczesnej muzyce Kościoła katolickiego w Polsce, nie sposób nie dostrzec fenomenu wszechobecnej, przenikającej nawet do liturgii piosenki religijnej. Dziś słyszana w różnych kontekstach w większości nie budzi już zaskoczenia, zdziwienia czy oburzenia, jak zdarzało się w latach sześćdziesiątych XX w., kiedy wraz z big beatem odważnie wprowadziła się do polskich świątyń, budząc ożywioną dyskusję. Przypisywana wówczas głównie młodzieży, zadomowiła się wśród katolików na dobre i stała naturalnym sposobem modlitwy i wyrażenia uczuć religijnych podczas różnego rodzaju praktyk, takich jak adoracje, nabożeństwa, rekolekcje, pielgrzymki.

Twórcami piosenek religijnych są nierzadko anonimowi amatorzy, a ich utwory poddane próbie czasu - odchodzą w zapomnienie. Z pewnością większe szanse przetrwania w pamięci mają te $\mathrm{z}$ nich, które znalazły się w śpiewnikach, jak również te tworzone przez profesjonalne zespoły popularnej muzyki chrześcijańskiej ${ }^{1}$, wykonywane podczas koncertów i zarejestrowane na płytach. Na amatorskie i profesjonalne można podzielić także wykonania tego typu repertuaru, zróżnicowane w zależności od możliwości muzycznych wspólnot, grup duszpasterskich, zespołów i schol.

W niniejszym artykule chciałabym przyjrzeć się genezie piosenki religijnej i cechom tego gatunku, jak również wskazać na jego wybrane przykłady zaprezentowane podczas pierwszego polskiego festiwalu poświęconego piosence religijnej, który w założeniach miał inspirować zarówno kompozytorów i poetów, jak i amatorów (zwłaszcza młodzież) do tworzenia nowych, wartościowych muzycznie i treściowo utworów. Istotne wydaje się także usytuowanie samego wydarzenia w szerszym kon-

I Chodzi o piosenki religijne wykonywane „profesjonalnie (oczywiście z różnym zakresem profesjonalizacji) w zespołowej prezentacji jako muzycznie zaaranżowany utwór wokalno-instrumentalny, w stylistycznej paraleli do wszystkich nurtów muzyki świeckiej”, zob.: Grzegorz Poźniak, „Popularna muzyka chrześcijańska. Próba zdefiniowania”, Liturgia Sacra. Liturgia-Musica-Ars I4 (2008) nr I, s. I27. 
tekście społecznym oraz określenie jego roli w kształtowaniu repertuaru religijnego w Polsce. Zadania te wpisują się w postulaty ks. Bolesława Bartkowskiego i ks. Grzegorza Poźniaka dotyczące potrzeby refleksji muzykologicznej nad piosenką religijną².

\section{KU NOWEJ MUZYCE}

Przyczyn wzrostu popularności piosenki religijnej należy dopatrywać się między innymi w przemianach, jakie dokonały się za sprawą Soboru Watykańskiego II (196265), a więc w odnowie liturgii, poszukiwaniu nowych dróg ewangelizacji, czy też dowartościowaniu roli osób świeckich. To przełomowe wydarzenie w dziejach Kościoła otworzyło drzwi nowej twórczości muzycznej i przyczyniło się do rozpowszechnienia piosenek religijnych, niezależnie od tego, jak można by ocenić skutki tego otwarcia z dzisiejszej perspektywy. Oczywiście piosenki religijne istniały już wcześniej - za ich prekursora uważa się francuskiego jezuitę Aimé Duvala (1918-84)³. Jego utwory pojawiły się w Polsce jeszcze przed Soborem Watykańskim II, ale wówczas nie opanowały kościołów na szerszą skalę4. Okres popularności tłumaczeń ewangelizacyjnych piosenek francuskich na język polski, takich autorów jak o. Aimé Duval, o. Maurice Cocagnac i Soeur Sourire (Siostra Uśmiech), przypadł głównie na lata sześćdziesiąte. W tym czasie powstawały już pierwsze piosenki w języku polskim, głównie autorstwa Zofii Konaszkiewicz (pisane pod pseudonimem Zofia Jasnota)'.

Sobór Watykański II odbył się w czasie, w którym na świecie, zwłaszcza w Stanach Zjednoczonych, intensywnie powstawały rozmaite ruchy młodzieżowe, tworzące się na fali dzieci kwiatów. Młodzieńcze poszukiwania równowagi, pokoju i szczęścia poprzez odrzucenie istniejących norm społecznych opartych na materializmie, konsumpcji i rywalizacji z czasem doprowadziły do wyłonienia się grup, które odnajdowały swoją drogę w różnych formach kontemplacji. Niektóre z nich za cel postawiły sobie odkrywanie Boga i Ewangelii, odrzucając kojarzone z hippisami narkotyki, seks i autodestrukcję oraz wykorzystując muzykę jako narzędzie głoszenia Słowa Bożego. Z czasem amerykańscy muzycy chrześcijańscy wykształcili odrębny nurt twórczości, zwany Contemporary Christian Music (CCM), mający swoje źródła w końcu lat pięćdziesiątych, czerpiący z rozwijającej się muzyki rockandrollowej ${ }^{6}$. Celem entu-

2 Grzegorz Poźniak, „Piosenka religijna w badaniach muzykologicznych w Polsce”, w: Konteksty piosenki religijnej. Norbert Blacha in memoriam, red. Grzegorz Poźniak, Opole 2013, s. I3-I4.

3 Piotr Wiśniewski, „Piosenka religijna”, w: Encyklopedia katolicka, red. Edward Gigilewicz, t. I5, Lublin 20II, k. 62I.

4 Małgorzata Danielewicz, Oazowa piosenka religijna. Struktura, funkcja, ideologia, Katolicki Uniwersytet Lubelski I99I (praca magisterska), s. 8.

5 Zofia Konaszkiewicz (Jasnota) jest również autorką znanych pieśni kościelnych, takich jak Byta cicha i piękna jak wiosna (Matka) i Zbawienie przyszto przez krzyż.

6 Tomasz Trzciński, Krótka historia chrześcijańskiej muzyki rockowej-czyli od psychodelii do Chrystusa, http://meakultura.pl/artykul/krotka-historia-chrzescijanskiej-muzyki-rockowej-czyli-od-psychodeliido-chrystusa-2284, dostęp io XI 2020. 
zjastów rocka wypełnionego religijną treścią, który początkowo był odrzucany przez środowiska chrześcijańskie jako prowadzący do grzechu, stało się dotarcie z ewangelicznym przesłaniem do jak największej liczby ludzi. Stopniowo nurt CCM zdobył dużą popularność na całym świecie, odznaczając się różnorodnością stylów muzycznych. Trzeba jednak zauważyć, że jego twórcy nie wywarli znaczącego wpływu na główny nurt rock and rolla. Kluczową rolę odgrywało przesłanie - modna i lubiana muzyka miała tylko przyciągnąć odbiorcę7.

Wspomniane zjawiska zaobserwowane w latach sześćdziesiątych na Zachodzie, tj. rozwijający się nurt popularnej muzyki chrześcijańskiej, posoborowe otwarcie się Kościoła na nową twórczość muzyczną i ogólne zainteresowanie gatunkiem piosenki, nasuwają pytanie o sposób implementacji zachodniego repertuaru religijnego w specyficznej sytuacji społeczno-politycznej PRL. W świetle badań Mariusza Gradowskiego, recepcja świeckiej muzyki popularnej następowała w Polsce nad wyraz szybko, głównie za sprawą indywidualnych muzyków, melomanów, dziennikarzy i działaczy muzycznych, którzy na różne sposoby pozyskiwali nagrania i nuty utworów rockandrollowych ${ }^{8}$. Wydaje się, że w przypadku popularnej muzyki chrześcijańskiej szanse na zdobycie płyt lub odnalezienie w zachodnich stacjach radiowych utworów religijnych mogły być bardziej ograniczone niż w przypadku muzyki świeckiej, choć oczywiście nie należy ich zupełnie wykluczać ${ }^{9}$. Niemniej jednak ważną rolę w przeszczepianiu religijnej muzyki Zachodu na grunt polski odegrały pojedyncze osoby, w tym przypadku duchowni, którzy w nowej muzyce religijnej dostrzegli nieistniejące przed Soborem Watykańskim II możliwości duszpasterskie.

Jednym z nich był ks. Stanisław Sierla, prekursor piosenek religijnych w Polsce i ich tłumacz, autor śpiewników, w tym śpiewnika Śpiewajcie Panu pieśń nowa (I97I), uważanego za pierwsze polskie wydawnictwo zawierające piosenki religijne. W I968 r. zorganizował w Katowicach ogólnopolskie sympozjum duszpasterskie dotyczące roli tego gatunku w duszpasterstwie młodzieży, a nawet - ku niezrozumieniu części duchowieństwa - wygłosił rekolekcje dla młodzieży przy akompaniamencie gitary ${ }^{\mathrm{Io}}$. Z kolei ks. Franciszek Blachnicki, założyciel znanego Ruchu Światło-Życie, utrzymywał kontakty ze wspólnotami życia chrześcijańskiego na Zachodzie, dla których ważnym aspektem formacyjnym był wspólny śpiew. W piosence religijnej widział zarówno na-

7 Steve Turner stwierdził nawet, że: „[p]odporządkowanie muzyki przesłaniu rodziło kaleki rock and roll. Nie było miejsca na intuicję i tajemnicę; każda piosenka musiała w ten czy inny sposób dotyczyć Jezusa. Odnosiło się wrażenie, że ludzie ci nie pragnęli zapisać się w historii muzyki rockandrollowej, lecz użyć jej jako konia trojańskiego, aby wyskoczyć z niego, potrząsając Bibliami”, zob.: Steve Turner, Gtód niebios. Rock \& roll w poszukiwaniu zbawienia, przekł. Tomasz Bieroń, Kraków 1997, s. I63.

8 Mariusz Gradowski, Big beat. Style i gatunki polskiej muzyki mtodzieżowej (1957-1973), Warszawa 2018, s. 199.

9 Przedstawiciele nurtu CCM jeszcze w latach siedemdziesiątych miewali problemy z wydawaniem płyt w świeckich wytwórniach fonograficznych, zob.: T. Trzciński, Krótka historia chrzésijańskiej muzyki rockowej.

Io Ewelina Małachowska, „Sacrosong '7I”, CzasyPismo O Historii Górnego Ślaska 5 (2014) nr I, s. 23. 
rzędzie ewangelizacyjne, jak i wychowawcze ${ }^{\mathrm{II}}$. Zainicjowany przez niego ruch, zwany potocznie Oazą, w znacznej mierze przyczynił się do rozpowszechnienia tego gatunku w Polsce. Nie sposób pominąć działalności ks. Leona Kantorskiego, proboszcza z Podkowy Leśnej, który, kierując się racjami duszpasterskimi, poszedł o krok dalej - propagował wprowadzanie muzyki młodzieżowej (big beatu) do liturgii ${ }^{12}$. To właśnie w jego parafii w styczniu 1968 r. po raz pierwszy zabrzmiała msza beatowa Pan przyjacielem moim autorstwa Katarzyny Gärtner, w wykonaniu zespołu Czerwono-Czarni, którą następnie wykonywał w Polsce i za granicą lokalny zespół Trapiści ${ }^{13}$. Jak widać, soborowa atmosfera otwarcia na nowe sposoby ewangelizacji, także poprzez muzykę, dotarła do Polski w zasadzie od razu.

Zachodnią piosenką religijną zainspirował się również twórca festiwalu Sacrosong, ks. Jan Palusiński - salezjanin, który podczas pobytu w Londynie w 1967 r. miał okazję uczestniczyć jako widz w spektaklach muzycznych towarzyszących kampanii ewangelizacyjnej amerykańskiego baptysty Billy'ego Grahama ${ }^{\mathrm{I}}$. Wydarzenie to, wzmocnione doświadczeniem spotkania z angielską młodzieżą z ruchu Church of England, która gościła w Duszpasterstwie Akademickim „Węzeł” w Łodziris, dało impuls do stworzenia festiwalu nowej twórczości religijnej w języku polskim.

Idee przyświecające twórcy nowego festiwalu koncentrowały się wokół stworzenia alternatywy dla monopolistycznej, ateistycznej kultury masowej czasów PRL, kiedy działalność stowarzyszeń i zrzeszeń młodzieży katolickiej była zakazana, a katechizacja w szkołach zniesiona. Chodziło o znalezienie przestrzeni do rozwoju dostępnej wszystkim kultury religijnej. Ważnym założeniem była aktywizacja środowisk twórczych, w tym pisarzy, poetów, kompozytorów, jak również plastyków, aktorów, i - co za tym idzie - związanie ich z Kościołem katolickim. Festiwal miał również ambicje odnowienia polskiej kultury muzycznej poprzez nową twórczość poetycką i muzyczną ${ }^{16}$. Sam ksiądz Palusiński widział swoje przedsięwzięcie jako miejsce poszukiwań i osiągnięć artystycznych, a także jako atrakcyjny i skuteczny sposób apostolstwa. Podkreślał również jego świąteczny charakter, zachęcający wierzących do odpoczynku,

II Franciszek Blachnicki, „Piosenka religijna a ewangelizacja”, Katecheta I4 (1970) nr 5, s. I95-I99.

I2 Leon Kantorski, „Beat w parafii”, Znak I92 (1970) nr 6, s. 759-765.

I3 Grzegorz Poźniak, „Msza beatowa «Pan przyjacielem moim» Katarzyny Gärtner w kontekście swojej epoki”, w: Unisono w wielogtosie, t. 2, W kręgu nazw i wartości, red. Radosław Marcinkiewicz, Sosnowiec 2OII, s. 23I.

I4 Bogusław Tracz, „O związkach Kościoła katolickiego z twórcami kultury w Polskiej Rzeczypospolitej Ludowej. Zapis wykładu Eryka Sztekkera wygłoszonego 24 X 1985 r. na kursie dla dyrektorów wydziałów do spraw wyznań”, Pamięć i Sprawiedliwośc. Pismo naukowe poświęcone historii najnowszej 33 (2019) nr I, s. 495, przyp. 2.

I5 Grażyna Wojczuk, „Sacrosong. Geneza i rozwój na przykładzie dwóch wybranych Sacrosongów: łódzkiego i krakowskiego", Roczniki Humanistyczne 3I (I983) nr I, s. 9I.

I6 Grażyna Wojczuk, „Sacrosong jako nowe zjawisko w polskiej kulturze religijnej ostatnich dziesięcioleci”, w: Dramat i teatr sakralny, red. Irena Sławińska, Wojciech Kaczmarek, Waldemar Sulisz, Maria Barbara Stykowa, Lublin I988, s. 2II. 
radości i zabawy. Traktował Sacrosong jako obrzęd, uwypuklając aspekty związane z tworzeniem wspólnoty i odniesieniem do sfery sacrum.

\section{HISTORIA SACROSONGÓW}

Festiwal Pieśni i Piosenki Religijnej Sacrosong ${ }^{17}$, zwany również Świętem Stworzenia Świata i Człowieka ${ }^{\mathrm{I}}$, odbywał się w różnych miastach Polski corocznie (z niewielkimi przerwami) w l. 1969-99, a jego najbardziej charakterystyczne cechy zarysowały się podczas pierwszych dziesięciu edycji (do roku 1978). Pierwszą edycję festiwalu ksiądz Palusiński zorganizował wraz z młodzieżą z Duszpasterstwa Akademickiego „Węzeł” w Łodzi, którego był opiekunem ${ }^{19}$. Wspólnie z nią sformułował założenia, regulamin i plan działania, który w 1968 r. przedstawił kardynałowi Karolowi Wojtyle - ówczesnemu Przewodniczącemu Komisji Episkopatu ds. Apostolstwa Świeckich. Kardynałowi zależało zarówno na aktywizacji środowisk twórczych, odpowiednim poziomie artystycznym, jak i na autonomii festiwalu, dzięki której możliwe stałoby się wejście w dialog z innymi religiami ${ }^{20}$. W związku z ostatnim zdecydował o tym, że Sacrosong nie znalazł się w oficjalnych strukturach Kościoła katolickiego: stosował się do wskazówek Episkopatu, jednak działał na własną odpowiedzialnośćc ${ }^{2}$. Ponadto kard. Wojtyła zaakceptował program festiwalu, a także objął go patronatem i ufundował nagrodę, tzw. puchar przechodni.

Sacrosong od początku był zaplanowany jako konkurs twórczości sakralnej różnego typu, a więc poezji, muzyki, teatru, plastyki. W zewnętrznej formie towarzyszyły mu elementy obrzędowe, takie jak procesja z symbolicznymi darami rozpoczynająca festiwal, wspólne wykonywanie pieśni przez wszystkich uczestników, uroczyste spotkanie zwane agapą kończące festiwal, a także elementy służące teatralizacji wydarzenia: wysunięty na pierwszy plan ołtarz, dekoracja kościoła, rozmieszczenie świateł ${ }^{22}$. Formuła festiwalowa zakładała ocenę utworów konkursowych przez jury, przyznawanie wykonawcom nagrody głównej (pucharu), innych nagród i dyplomów oraz obecność publiczności. Zdarzało się, że podczas Sacrosongów odbywały się wy-

I7 Już sama nazwa „Sacrosong”, będąca połączeniem łacińskiego słowa sacer (święty) i angielskiego song (piosenka), nasuwa skojarzenia z jednej strony z tradycją Kościoła katolickiego, którego językiem własnym jest łacina, z drugiej - z nowoczesnością utożsamianą z krajami Zachodu.

I8 Pomysł takiej nazwy został zaczerpnięty z eseju Antoniego Gołubiewa „Święto stworzenia świata”, opublikowanego w Tygodniku Powszechnym w I958 r. (nr 7, s. I-2). Festiwale Sacrosong zakładały celebrację nieistniejącego w kalendarzu liturgicznym święta stworzenia świata i człowieka. Miały także być wkładem ludzi w ciągłe stwarzanie go na nowo poprzez oddanie czci Bogu we wspólnym śpiewie.

I9 Milena Przybysz, Wyspy wolności. Duszpasterstwo akademickie w Eodzi 1945-1989, Łódź 2008, s. I4I-I42.

20 Wiadomo, że podczas festiwalu występowali przedstawiciele grekokatolików, protestantów i adwentystów, zob.: G. Wojczuk, „Sacrosong. Geneza i rozwój”, s. I25.

2I Przemysław Ruchlewski, „Działania Służby Bezpieczeństwa podczas toruńskiego festiwalu «Sacrosong 73"”, w: Diecezja Chetmińska w czasach komunizmu (I945-I99o), red. Wojciech Polak, Waldemar Rozynkowski, Jan Sziling, t. I, Pelplin 2008, s. 309.

22 G. Wojczuk, „Sacrosong jako nowe zjawisko”, s. 210, 2 I4. 
stępy teatralne, wystawy malarstwa i rzeźby, wieczory poezji, konkursy recytatorskie, kiermasze książek, a także konferencje i dyskusje ${ }^{23}$.

Konkurs w ramach festiwalu w zamierzeniu ks. Palusińskiego miał na celu przede wszystkim wzbogacenie repertuaru religijnego o nowe utwory w języku polskim, których wówczas było jeszcze niewiele - mniejszy akcent położony był na promowanie solistów i zespołów, czy ostatecznie nawet na samo wykonanie:

Przyjęta forma Sacrosongu - jako konkursu na utwory, a nie na wykonawców (czy wykonawstwo) - ma przyczyniać się do powstawania nowych artystycznych miniatur religijnych, świadectw i owoców żywej wiary, lecz zarazem ma ustrzec przed kokieterią, tanią fascynacją czy kreowaniem „gwiazdek”24.

W pierwszych edycjach Sacrosongu wykonywano głównie piosenki religijne, ale z czasem na scenie festiwalowej można było usłyszeć pieśni, msze, kantaty, oratoria, powstałe na zamówienie organizatorów. Z roku na rok na festiwal przybywało coraz więcej wykonawców - początkowo byli to głównie soliści i zespoły wokalno-instrumentalne, później zaś także chórki dziecięce, schole, chóry ${ }^{25}$. Podczas pierwszego Sacrosongu w Łodzi do konkursu mogli przystąpić indywidualni wykonawcy, zespoły młodzieżowe (do siedmiu osób w wieku do 30 lat) oraz grupy z wyższych seminariów duchownych. Soliści wykonywali dwie piosenki: jedną własną, jedną przesłaną wcześniej przez organizatorów w formie tekstu i nut (napisaną specjalnie na festiwal), zespoły natomiast - maksymalnie pięć piosenek, z czego uprzednio przekazane do realizacji były dwie z nich. Utwory własne uczestników, zgłaszane przed festiwalem, podlegały ocenie komitetu organizacyjnego, który mógł je przyjąć lub odrzuciće ${ }^{6}$. $Z$ biegiem lat regulamin ulegał modyfikacjom, jednak idea pozostała niezmienna.

W festiwale sacrosongowe byli zaangażowani literaci, kompozytorzy, plastycy przygotowujący dekoracje, pracownicy techniczni (m.in. akustycy), wykonawcy (młodzież szkolna i akademicka), muzycy orkiestry symfonicznej oraz członkowie jury $^{27}$. W celu włączenia twórców w kreowanie wydarzenia ks. Palusiński co roku prosił listownie kilkudziesięciu poetów i pisarzy o teksty pieśni i piosenek - otrzymywał ich około stu. Wraz z polonistami z Katolickiego Uniwersytetu Lubelskiego wybierał z nich ok. 35-40, by następnie przekazać je do opracowania kompozytorom ${ }^{28}$. Ponadto Sacrosongi były poprzedzone obozami przygotowawczymi, podczas których odbywały się próby solistów i orkiestry oraz doprecyzowywano program festiwalu. Po trzech pierwszych edycjach wydarzenia zaczęły powstawać także Sacrosongi die-

23 G. Wojczuk, „Sacrosong. Geneza i rozwój”, s. I3I-I32.

24 Jan Palusiński, „Sacrosong. Festiwal - święto - obrzęd”, Ethos 6 (1993) nr 3, s. 256.

25 G. Wojczuk, „Sacrosong jako nowe zjawisko”, s. 2II.

26 G. Wojczuk, „Sacrosong. Geneza i rozwój”, s. Ioo.

27 Jarosław Szarek, „Służba Bezpieczeństwa wobec IV Festiwalu Piosenki Religijnej «Sacrosong-72»”, w: Kościót w godzinie próby (1945-1989). Nieznane dokumenty i świadectwa, red. Tomasz Balon-Mroczka, Jarosław Szarek, Kraków 2006, s. 345.

28 P. Ruchlewski, „Działania Służby Bezpieczeństwa”, s. 3 I2. 
cezjalne, pełniące rolę eliminacji. Niektóre z nich funkcjonowały jako samodzielne wydarzenia ${ }^{29}$.

W jury festiwali Sacrosong zasiadali przedstawiciele różnych środowisk: muzykolodzy, muzycy, literaci, aktorzy, duchowni, dziennikarze. Wśród nich znaleźli się m.in. Janina Burke-Bielicka, ks. Józef Gawor, Antoni Gołubiew, Wojciech Kilar, Stefan Kisielewski, ks. Jerzy Pikulik, Franciszek Ryling, Stefan Sawicki, ks. Stanisław Sierla, Irena Sławińska, Zbigniew Soja, Anna Szałaśna, Zofia Śliwińska, Jan Węcowski, a także cudzoziemcy - Horst Frölich i Walter Karlberger. W ramach konkursu jury oceniało przede wszystkim piosenkę (aranż, melodię, dykcję, tekst) oraz wykonanie (muzykę, wokal) ${ }^{30}$.

W Festiwalu Pieśni i Piosenki Religijnej na przestrzeni lat brały udział także środowiska katolickie m.in. z NRD, Czechosłowacji, Węgier, Jugosławii, Bułgarii i dawnego ZSRR, których przedstawiciele przyjeżdżali na Sacrosong mimo obaw związanych z represjami ${ }^{31}$. Również sami organizatorzy imprezy zmagali się z różnego rodzaju działaniami utrudniającymi lub wręcz stawiającymi pod znakiem zapytania powodzenie jej kolejnych edycji. Już przed pierwszą edycją festiwalu w Łodzi Służba Bezpieczeństwa usiłowała go odwołać, a kiedy to się nie udało - utrudnić organizację i osłabić jego zasięg ${ }^{32}$. W tym celu aparat władzy różnymi metodami rozpoznawał zakres imprezy i osoby zaangażowane, obniżał jej rangę, nie dopuszczał do wykorzystania przez organizatorów instytucji państwowych i placówek oświatowo-kulturalnych, zabezpieczał przebieg festiwalu, a także dokumentował działania organizatorów ${ }^{33}$.

$\mathrm{Z}$ uwagi na zakaz zgromadzeń publicznych festiwale Sacrosong odbywały się w kościołach jako nabożeństwo. Forma festiwalowa sprzyjała swobodnemu zachowaniu publiczności, która nagradzała uczestników oklaskami i prosiła o „bisy”. Spontaniczne reakcje młodzieży dotyczyły szczególnie piosenek zbliżonych do ówczesnej muzyki młodzieżowej ${ }^{34}$. Organizacja wydarzenia tego typu w kościele, traktowanym przez katolików jako miejsce święte, budziła sprzeciw części duchowieństwa i części wiernych należących do starszego pokolenia, którzy zarzucali twórcom festiwalu „robienie cyrku z domu bożego"35. Anna Szałaśna, członkini jury podczas kilku pierw-

Ibid.; zob. też: Bogumił Mazurczyk, „Śląski Sacrosong”, Śląskie Studia Historyczno-Teologiczne (1994-1995) nr 27/28, s. 415-424.

30 G. Wojczuk, „Sacrosong. Geneza i rozwój”, s. IO5.

3I J. Palusiński, „Sacrosong. Festiwal - święto - obrzęd”, s. 256.

32 Krzysztof Kolasa, „Festiwal Piosenki Religijnej «Sacrosong '69» w Łodzi «na cenzurowanym»”, w: W kregu kultury PRL, t. 3, Muzyka. Rodzaje i style, red. Karolina Bittner, Dorota Skotarczak, Poznań 2017, s. 158.

33 Piotr Głuchowski, Jacek Hołub, Ojciec Tadeusz Rydzyk. Imperator, Warszawa 2013, s. 43. Obszerne zeznania w sprawie przynajmniej dwóch edycji Sacrosongu składał w bezpiece Jan Węcowski (TW „Jasio") - muzykolog, kompozytor, literat. Prowadził także działania utrudniające organizację i pomyślny przebieg festiwalu, zob.: K. Kolasa, „Festiwal Piosenki Religijnej”, s. I55, I6I; J. Szarek, „Służba Bezpieczeństwa wobec IV Festiwalu", s. 352.

34 P. Ruchlewski, „Działania Służby Bezpieczeństwa”, s. 337.

35 K. Kolasa, „Festiwal Piosenki Religijnej”, s. I6I-I62. 
szych edycji wydarzenia, w rozmowie wspominała oburzenie starszych kobiet, które słysząc piosenki z akompaniamentem gitary (!), wykrzyknęły „obraza Boska!”, wzięły kapelusze i płaszcze i opuściły kościół ${ }^{36}$. Tego typu reakcje nie budzą zdziwienia, jeśli wziąć pod uwagę skalę przemian w obrębie świątyni, jaka dokonała się w latach sześćdziesiątych XX w., szczególnie tych związanych z odnową liturgii. W tym kontekście piosenki aranżowane przez młodzież w stylu bigbitowym przy akompaniamencie gitar elektrycznych wymykały się wszelkim normom i dotychczasowym przyzwyczajeniom.

Zespoły występujące na festiwalu Sacrosong przybierały rozmaite, nieraz oryginalne nazwy, takie jak: Gitary Niepokalane, Hekatomby, Huncwoty, Jutrzenka, Juwentus, Kamino, Pomorzanie, Roncallowie, Signum, Szpaczki. Część z nich została utworzona specjalnie na to wydarzenie i albo kontynuowała swoją działalność przy parafii, albo wystąpiła jednorazowo. Część zaś już przed festiwalem funkcjonowała przy kościołach, jak na przykład zespół bigbitowy Truwersi założony przez o. Tadeusza Rydzyka przy kościele oo. redemptorystów w Toruniu. Choć ostatecznie grupie nie udało się wystąpić podczas Sacrosongu (opiekun nie wysłał Truwersów na eliminacje z powodu obaw o represje członków zespołu, którzy byli uczniami szkół muzycznych ${ }^{37}$ ), to regularnie spotykała się na próbach i współtworzyła niedzielną mszę, otrzymując nawet wynagrodzenie. Wiadomo, że w składzie tego zespołu znajdowały się wówczas: gitara solowa, basowa, perkusja, organy elektronowe i skrzypce ${ }^{38}$.

Za ostatni Sacrosong o zasięgu ogólnopolskim uznaje się jego trzydziestą edycję z 1999 r.39. Kontynuacji tego wydarzenia miały przeszkodzić trudności finansowe, jednak sam pomysł organizowania sceny dla piosenek religijnych przetrwał i jest realizowany w różnych kontekstach działalności Kościoła katolickiego. Przykładem może być choćby zwyczaj urządzania festiwalu sacrosongowego podczas Warszawskiej Pieszej Pielgrzymki na Jasną Górę, w trakcie którego poszczególne jej grupy prezentują utwory, które stały się przebojami podczas drogi.

\section{„ŚWIĘTE PIOSENKI"}

Istotne z perspektywy omawianego festiwalu jest określenie cech gatunkowych tytułowego „sacrosongu” - „świętej piosenki”, czy też piosenki religijnej (w odróżnieniu od świeckiej). Małgorzata Danielewicz definiuje ją jako „formę, którą charakteryzuje prostota, chwytliwość i łatwa przyswajalność, chociaż występują również utwory o pewnym stopniu trudności, ze skomplikowaną rytmiką. Melodyka i ryt-

36 Informacja przekazana podczas rozmowy z Anną Szałaśną w dn. 27 I 2020.

37 P. Głuchowski, J. Hołub, Ojciec Tadeusz Rydzyk. Imperator, s. 46-47.

38 Ibid., s. 40-42.

39 P. Ruchlewski, „Działania Służby Bezpieczeństwa”, s. 316. 
mika piosenek religijnych nawiązuje w swoim charakterze do piosenek świeckich, stąd są one lekkie, śpiewne i szlagierowe" ${ }^{\circ}$. Teksty piosenek religijnych odwołują się zazwyczaj do sytuacji życiowych, ludzkich przeżyć, stanów emocjonalnych oraz obfitują w refleksje filozoficzne ${ }^{4 I}$. Nawiązują także do scen biblijnych, zachęcając do życia według wartości chrześcijańskich. Zawierają wiele powtórzeń, metafor, luźnych skojarzeń i point.

Piosenki religijne są proste tonalnie, oparte na triadzie harmonicznej i akordach na stopniach pobocznych, rzadko rozbudowanych o sekstę, septymę lub nonę ${ }^{42}$. Zdarzają się zmiany z tonacji durowej na molową i na odwrót. Ponadto pojawia się w nich muzyka taneczna, a rytmikę cechują kontrasty, synkopy, rytmy punktowane, pauzy na mocnych częściach taktu, zmiany metrum. Melodie piosenek religijnych odznaczają się dużym ambitus i skokami interwałowymi, są też bogate w chromatykę oraz podwyższone i obniżone interwały. Obfitują w progresje, rozłożone akordy, pochody tercji, seksty, septymy i oktawy.

Poza treścią i melodią piosenek religijnych nie mniej ważne jest ich wykonanie, które w założeniach ma odpowiadać „duchowemu charakterowi” tego rodzaju twórczości. Wspominał o tym ks. dr Antoni Reginek, przewodniczący jury jednego ze Śląskich Sacrosongów w Katowicach:

Dobra piosenka religijna powinna odznaczać się płynną, oryginalną melodyką, wartościowym tekstem i jak sama nazwa wskazuje, ma mieć w sobie ducha religijnego. Zespoły, które w konkursie sacrosongowym zostały ocenione najniżej, prezentowały hałaśliwą muzykę świecką, dyskotekową, nierzadko na miernym poziomie, w której zabrakło pierwiastka religijnego, a tekst może nawet wartościowy, został zagłuszony dźwiękami instrumentów ${ }^{43}$.

Śledząc literaturę dotyczącą muzyki kościelnej, a zwłaszcza liturgicznej, napotkać można na wiele stwierdzeń mówiących o duchowym, nie dającym się do końca uchwycić wymiarze twórczości religijnej. Także w przytoczonym fragmencie jest mowa o „duchu religijnym” i „pierwiastku religijnym”, jakim powinny odznaczać się sacrosongowe utwory. Na podstawie lektury posoborowych dokumentów Kościoła katolickiego dotyczących muzyki można się domyślać, że w praktyce chodzi z jednej strony o unikanie wykonań budzących skojarzenia z muzyką świecką - głośnych, z wyrá́nym rytmem, lecz także prezentowanych na instrumentach kojarzonych z muzyką rozrywkową, z drugiej - o wprowadzanie atmosfery sprzyjającej modlitwie, prowadzącej do spokoju, skupienia, bądź umiarkowanej radości. Postulaty te zasadniczo dotyczą jednak repertuaru liturgicznego i w przypadku piosenek religijnych

40 M. Danielewicz, Oazowa piosenka religijna, s. 87.

4I Stanisław Ziemiański, „Pieśni i piosenki religijne”, w: Polska muzyka religijna - między epokami $i$ kulturami, red. Krystyna Turek, Bogumiła Mika, Katowice 2006, s. II9-I20.

42 P. Wiśniewski, „Piosenka religijna”, k. 622.

43 Cyt. za: B. Mazurczyk, „Śląski Sacrosong”, s. 419 (materiał zarejestrowany na kasecie magnetofonowej ze zbiorów autora). 
(wyłączonych z liturgii) wydają się z gruntu nie do spełnienia. Już sama treść i materia muzyczna zbliżone są do repertuaru świeckiego, a instrumenty towarzyszące piosenkom - te same jak w przypadku muzyki popularnej.

Niemniej jednak organizatorom festiwalu Sacrosong zależało na tym, by twórcy piosenek aspirowali do pisania utworów wartościowych muzycznie i głębokich treściowo (postulat ten znalazł się we wstępie do projektu regulaminu) ${ }^{44}$. Zapraszali oni do współpracy znanych i cenionych poetów, pisarzy i kompozytorów. Wśród autorów tekstów znaleźli się m.in. Zbyszko Bednorz, Roman Brandstaetter, Ernest Bryll, Maria Józefacka, Anna Kamieńska, Jan Bolesław Ożóg, ks. Jan Twardowski, Jerzy Zagórski, wśród twórców muzyki natomiast - Jerzy Bauer, Edward Bury, Jan Fotek, Andrzej Hanzelewicz, Juliusz Łuciuk, Mariusz Matuszewski, ks. Jan Pryputniewicz, Marian Sawa, Andrzej Zieliński.

Nie sposób wymienić wszystkich utworów powstałych na zamówienie festiwalu oraz komponowanych przez samych uczestników, nie zachowała się bowiem pełna dokumentacja tego wydarzenia. Tylko część z nich stała się na tyle popularna, że weszła do repertuaru wspólnot katolickich. Warto wspomnieć o słynnej piosence Barka, którą prawdopodobnie po raz pierwszy oficjalnie zaprezentowano w czasie Sacrosongu w Przemyślu w roku 1975. Wykonał ją zespół z Oświęcimia, prowadzony przez salezjanów, złożony z około piętnasto-, szesnastoletnich chłopców ubranych w stroje górnicze i grających na gitarach elektrycznych. Anna Szałaśna wspominała, że utwór wzbudził wiele emocji: od zdziwienia, przez zachwyt dobrym wykonaniem, po rozczarowanie wobec przyznania pierwszej nagrody innej piosence ${ }^{45}$. Nie zdawano sobie wówczas sprawy, że południowoamerykańska melodia Barki przybyła do Polski wraz z salezjaninem, ks. Stanisławem Skopiakiem, a jej wolnego tłumaczenia z języka hiszpańskiego podjął się w roku 1974 lub 1975 jego współbrat, ks. Stanisław Schmidt ${ }^{46}$. Salezjanie rozpowszechniali ją wśród młodzieży, jednak wydaje się, że do czasu festiwalu nie była znana szerszej publiczności. O jej niezwykłej popularności świadczy fakt, że już w 1979 r. zabrzmiała w Gnieźnie podczas pielgrzymki Jana Pawła II, a sam papież śpiewał ją z pamięci ${ }^{47}$.

Barka jest jednak przykładem wyjątkowym, jeśli chodzi o recepcję wśród katolików. Chcąc ustalić, na ile piosenki z I Sacrosongu weszły do praktyki życia wspólnot, Grażyna Wojczuk na początku lat osiemdziesiątych przeanalizowała dostępne śpiewniki z tego typu repertuarem, przyjmując za kryterium popularności fakt obecności danego utworu w tychże wydawnictwach. Jej rekonesans ujawnił, że najczęściej były

44 G. Wojczuk, „Sacrosong. Geneza i rozwój”, s. Io9.

45 Informacja przekazana podczas rozmowy z Anną Szałaśną w dniu 27 I 2020 roku.

46 Barka - ulubiona pieśń Jana Pawta II, historia pieśni (rozmowa z ks. Stanisławem Schmidtem), http:// www.kuria.pijarzy.pl/polecamy/w_wolnym_czasie/czy_wiesz_ze.../\%22barka\%22_-_ulubiona_piesn_ jana_pawla_ii,_historia_piesni_d7353_pol.html, dostęp I8 I 202I.

47 Ibid. 
wydawane takie piosenki, jak Drogowskaz, Na wszystkich drogach życia, Naucz nas, Panie, Wędrówka, Ciągle marzę o Twym niebie, Do Ciebie, Boże, należeć chce, Chwyć Boga dtoń, Maryjo, naucz mnie, Kiedyś powróci Pan, czyli zarówno utwory autorów polskich, jak i tłumaczenia piosenek zagranicznych ${ }^{48}$. Nie znalazł się wśród nich zwycięski utwór Czarna Madonna do słów Macieja Józefa Kononowicza, z muzyką Jerzego Bauera ${ }^{49}$, notabene w literaturze często błędnie utożsamiany ze znaną powszechnie pieśnią Czarna Madonna (z incipitem „Jest zakątek na tej ziemi”) autorstwa Alicji Gołaszewskiej - twórczyni repertuaru religijnego i organistki na Jasnej Górze. Znamienne jednak, że wymienione tytuły można znaleźć w aktualnych śpiewnikach tylko sporadycznie ${ }^{50}$. Fakt ten sugeruje, że spora część repertuaru sacrosongowego wyszła z użycia, choć należałoby się zastanowić, czy przyjęte kryterium popularności danej piosenki jest najlepszym z możliwych. Stan zachowania utworów festiwalowych w społecznościach katolickich w Polsce z pewnością wymaga pogłębionych badań.

Istnieje kilka powodów, dla których część repertuaru festiwalowego nie weszła do użytku wspólnot katolickich, a część po okresie popularności uległa zapomnieniu. Zdaniem Grażyny Wojczuk repertuar festiwalowy miałby szanse utrzymania się w praktyce wykonawczej dłużej, gdyby środowisko związane z Sacrosongami ściślej współpracowało z ruchem oazowym - wówczas bowiem repertuar ten związałby się z różnymi formami pobożności praktykowanej w kręgach młodzieży ${ }^{5 I}$. Twórczość oazowa raczej nie była nagradzana w konkursie, co może wynikać z faktu, że festiwal promował tylko utwory napisane na zamówienie i najbardziej wartościowe utwory uczestników. Być może także część utworów, które wyszły spod ręki kompozytorów nie trafiała w gusta młodzieży zafascynowanej trendami obecnymi wówczas w muzyce świeckiej. Ostatecznie jednak piosenka jest rzeczywistością ulotną, rządzącą się prawami mody i preferencji ludzi danego czasu - te z kolei uwikłane są w emocjonalność i duchowość, które generują zapotrzebowanie na określoną muzykę i teksty.

48 G. Wojczuk, „Sacrosong. Geneza i rozwój”, s. I07.

49 Zapis nutowy tego utworu jest dostępny pod adresem: http://jerzybauer.com/pl/katalog-utworow/, dostęp Is I 202I.

50 W powszechnie używanych śpiewnikach: Pójdę do Nieba piechotą: śpiewnik pielgrzymkowy (1997), Śpiewajmy Panu: śpiewnik pieśni i piosenek religijnych (2004), Śpiewnik pielgrzymkowy. Zbiór pieśni i piosenek pielgrzymkowych, tradycyjnych i liturgicznych oraz nowych piesni na Trzecie Tysiąlecie (2008) oraz w internetowej bazie spiewnikreligijny.pl (dostęp 25 I 202I) odnaleziono już tylko pięć z dziewięciu utworów: Na wszystkich drogach życia (3), Naucz nas, Panie (2), Drogowskaz (I), Kiedyś powróci Pan (I), Maryjo, naucz mnie (I).

5I G. Wojczuk, „Sacrosong. Geneza i rozwój”, s. I27-I28. 


\section{Z PERSPEKTYWY CZASU}

$\mathrm{Na}$ koniec warto określić rolę, jaką festiwale Sacrosong odegrały w rozwoju religijnej kultury muzycznej w Polsce. Z pewnością przyczyniły się one do powstawania nowego repertuaru religijnego w języku polskim, który następnie był użytkowany podczas katechez, pielgrzymek, spotkań parafialnych i duszpasterskich, jak również przyczynił się do promocji i popularyzacji gatunku piosenki religijnej pośród szerokich kręgów katolików. Pobudzały one do zaangażowania w działalność religijną zarówno młodzież, jak i artystów, którzy zyskali możliwość prezentacji swoich utworów na ogólnopolskiej scenie. Stały się także inspiracją do organizacji w Polsce tygodni kultury chrześcijańskiej (pierwszy odbył się w Warszawie w 1974 r.) oraz innych festiwali o mniejszym zasięgu (Sacrosongi diecezjalne, Cantate Deo, Maria Song) ${ }^{52}$.

Festiwal Sacrosong był wydarzeniem mocno wpisanym w swoje czasy. Z jednej strony stanowił owoc soborowych uchwał i reform, z drugiej zaś przypadł na okres rozkwitu piosenkarstwa świeckiego i muzyki rockandrollowej. Wplótł się także w specyficzną sytuację polską, stając się - wobec działań władzy komunistycznej mających na celu ateizację społeczeństwa - miejscem propagowania wartości chrześcijańskich oraz przestrzenią wolności wypowiedzi i wyrażania uczuć religijnych. Jak wspominał o. Jan Góra OP: „Piosenka była wtedy tak ważna, iż wydawało się, że porwie nas wszystkich. Kiedy szalał reżim komunistyczny, nie bacząc na przeszkody, spotykaliśmy się na zakazanych obozach i śpiewaliśmy!"’3. Warto zauważyć, że autorzy tekstów piosenek religijnych w okresie PRL w większości stronili od podejmowania tematów społeczno-politycznych. Ich twórczość była ukierunkowana głównie na treści religijne, prowadzące ludzi do wiary ${ }^{54}$.

Pomimo działań podejmowanych przez organizatorów Sacrosongu, mających na celu transmisję i memoryzację nowego repertuaru religijnego w języku polskim, wydaje się, że nie osiagnęli oni w pełni zamierzonych celów. Przyczyną były w znacznej mierze utrudnienia i ograniczenia ze strony władzy komunistycznej, polegające m.in. na uniemożliwieniu wydania płyt oraz śpiewników z utworami z kolejnych edycji. Tym samym potencjał nowych utworów, w tym pisanych przez profesjonalistów na zamówienie, nie został w pełni wykorzystany.

W kontekście potrzeby mecenatu Kościoła katolickiego, polegającego na zamawianiu utworów do użytku liturgicznego, ks. Stanisław Ziemiański sformułował wobec Sacrosongów zarzut marnowania okazji do powstawania pieśni przydatnych do liturgii. Jego zdaniem zamiast tego premiowano „efekt estradowy, wartość muzycznej formy

52 G. Wojczuk, „Sacrosong jako nowe zjawisko”, s. 215-2I6.

53 Jan Góra OP, Historia moich starań o to, by lud śpiewat, https://opoka.org.pl/biblioteka/T/TA/TAL/ by_lud_spiewal.html, dostęp 6 XI 2020.

54 Grzegorz Poźniak, Popularna muzyka chrześcijańska w Polsce. Teologiczno-muzykologiczne spojrzenie, Opole 2009, s. 203. 
i piękno wykonania"ss. Oczywiście sam postulat autora jest w pełni zasadny, jednak sceniczna forma prezentacji wydaje się nieadekwatna dla repertuaru ściśle związanego z czynnościami obrzędowymi związanymi z kultem religijnym, nawet jeśli w tym przypadku scenę umieszczano w przestrzeni sakralnej. Trzeba także zauważyć, że organizatorzy zamawiali nie tylko piosenki, lecz również pieśni i utwory muzyki klasycznej.

Ostatecznie Sacrosong wyniósł na piedestał głównie piosenkę religijną - czasem nazbyt wychwalaną przez grupy działające w Kościele katolickim, czasem zaś przesadnie krytykowaną przez środowiska duchownych, muzyków kościelnych i liturgistów. Trzeba jej jednak przyznać istotne miejsce w posoborowej rzeczywistości: w ewangelizacji, katechizacji i pozaliturgicznych praktykach religijnych. Jest bowiem jednym ze sposobów ekspresji współczesnego człowieka religijnego i jednocześnie wiele mówi o nim samym - o jego potrzebach, emocjonalności, sposobie przeżywania wiary czy upodobaniach muzycznych.

\section{BIBLIOGRAFIA}

„Barka - ulubiona pieśń Jana Pawła II, historia pieśni”. Rozmowa z ks. Stanisławem Schmidtem, http://www.kuria.pijarzy.pl/polecamy/w_wolnym_czasie/czy_wiesz_ze.../\%22barka\%22_-ulubiona_piesn_jana_pawla_ii,_historia_piesni_d7353_pol.html, dostęp I8 I 202I.

Bauer, Jerzy. „Katalog utworów”, http://jerzybauer.com/pl/katalog-utworow/, dostęp I5 I 202I. Blachnicki, Franciszek. „Piosenka religijna a ewangelizacja”. Katecheta I4, nr 5 (1970): 195-199. Danielewicz, Małgorzata. „Oazowa piosenka religijna. Struktura, funkcja, ideologia”. Praca magisterska, Katolicki Uniwersytet Lubelski, I99I.

Głuchowski, Piotr i Jacek Hołub. Ojciec Tadeusz Rydzyk. Imperator. Warszawa: Agora, 2013.

Gołubiew, Antoni. „Święto stworzenia świata”. Tygodnik Powszechny I2, nr 7 (I958): I-2.

Góra, Jan. „Historia moich starań o to, by lud śpiewał”, https://opoka.org.pl/biblioteka/T/ TA/TAL/by_lud_spiewal.html, dostęp 6 XI 2020.

Gradowski, Mariusz. Big beat. Style i gatunki polskiej muzyki mtodzieżowej (1957-1973). Warszawa: Oficyna Wydawnicza ASPRA-JR, 2018.

Kantorski, Leon. „Beat w parafii”. Znak I92, nr 6 (1970): 759-765.

Kolasa, Krzysztof. „Festiwal Piosenki Religijnej «Sacrosong '69» w Łodzi «na cenzurowanym»”. W: W kręu kultury PRL. T. 3, Muzyka. Rodzaje i style, red. Karolina Bittner, Dorota Skotarczak, I49-I64. Poznań: Oddział Instytutu Pamięci Narodowej - Komisji Ścigania Zbrodni przeciwko Narodowi Polskiemu, Instytut Historii UAM, 2017.

Małachowska, Ewelina. „Sacrosong '7ı”. CzasyPismo O historii Górnego Ślaska 5, nr I (2014): 22-29.

Mazurczyk, Bogumił. „Śląski Sacrosong”. Śląskie Studia Historyczno-Teologiczne 27/28 (1994-95): $4 \mathrm{I} 5-424$.

Palusiński, Jan. „Sacrosong. Festiwal - święto - obrzęd”. Ethos. Kwartalnik Instytutu Jana Pawta II KUL 6, nr 3 (1993): 248-26I.

55 Stanisław Ziemiański, „Kompozytor a nowa pieśń kościelna”, w: Śpiew wiernych w odnowionej liturgii, red. Remigiusz Pośpiech, Piotr Tarlinski, Opole 1993, s. 38. 
Poźniak, Grzegorz. „Msza beatowa «Pan przyjacielem moim» Katarzyny Gärtner w kontekście swojej epoki”. W: Unisono w wielogtosie. T. 2, W kręgu nazw i wartości, red. Radosław Marcinkiewicz, 227-236. Sosnowiec: Wydawnictwo GAD Records, 20II.

Poźniak, Grzegorz. „Piosenka religijna w badaniach muzykologicznych w Polsce”. W: Konteksty piosenki religijnej. Norbert Blacha in memoriam, red. Grzegorz Poźniak, II-20. Opole: Redakcja Wydawnictw Wydziału Teologicznego Uniwersytetu Opolskiego, 2013.

Poźniak, Grzegorz. „Popularna muzyka chrześcijańska. Próba zdefiniowania”. Liturgia Sacra. Liturgia - Musica - Ars I4, nr I (2008): I27-I34.

Poźniak, Grzegorz. Popularna muzyka chrześcijańska w Polsce. Teologiczno-muzykologiczne spojrzenie. Opole: Redakcja Wydawnictw Wydziału Teologicznego Uniwersytetu Opolskiego, 2009.

Przybysz, Milena. Wyspy wolności. Duszpasterstwo akademickie w Łodzi 1945-1989. Łódź: Instytut Pamięci Narodowej. Komisja Ścigania Zbrodni przeciwko Narodowi Polskiemu, 2008.

Ruchlewski, Przemysław. „Działania Służby Bezpieczeństwa podczas toruńskiego festiwalu "Sacrosong 73»". W: Diecezja Chetminska w czasach komunizmu (I945-199o), red. Wojciech Polak, Waldemar Rozynkowski, Jan Sziling. T. I, 309-338. Pelplin: Wydawnictwo Bernardinum, 2008.

Szarek, Jarosław. „Służba Bezpieczeństwa wobec IV Festiwalu Piosenki Religijnej «Sacrosong-72»". W: Kościót w godzinie próby (1945-1989). Nieznane dokumenty i świadectwa, red. Tomasz Balon-Mroczka, Jarosław Szarek, 34I-353. Kraków: Rafael, 2006.

Tracz, Bogusław. „O związkach Kościoła katolickiego z twórcami kultury w Polskiej Rzeczypospolitej Ludowej. Zapis wykładu Eryka Sztekkera wygłoszonego 24 X I985 roku na kursie dla dyrektorów wydziałów do spraw wyznań”. Pamięć i Sprawiedliwość. Pismo naukowe poświęcone historii najnowszej 33, $\mathrm{nr}$ I (2019): 494-52I.

Trzciński, Tomasz. „Krótka historia chrześcijańskiej muzyki rockowej - czyli od psychodelii do Chrystusa", http://meakultura.pl/artykul/krotka-historia-chrzescijanskiej-muzyki -rockowej-czyli-od-psychodelii-do-chrystusa-2284, dostęp ıо XI 2020.

Turner, Steve. Gtód niebios. Rock \& roll w poszukiwaniu zbawienia, przekł. Tomasz Bieroń. Kraków: Wydawnictwo Znak, 1997.

Wiśniewski, Piotr. „Piosenka religijna”. W: Encyklopedia katolicka, red. Edward Gigilewicz. T. 15, 62I-622. Lublin: Wydawnictwo Towarzystwa Naukowego Katolickiego Uniwersytetu Lubelskiego, 20II.

Wojczuk, Grażyna. „Sacrosong jako nowe zjawisko w polskiej kulturze religijnej ostatnich dziesięcioleci”. W: Dramat $i$ teatr sakralny, red. Irena Sławińska, Wojciech Kaczmarek, Waldemar Sulisz, Maria Barbara Stykowa, 209-217. Lublin: Redakcja Wydawnictw Katolickiego Uniwersytetu Lubelskiego, 1988.

Wojczuk, Grażyna. „Sacrosong. Geneza i rozwój na przykładzie dwóch wybranych Sacrosongów: łódzkiego i krakowskiego". Roczniki Humanistyczne 3I, nr I (I983): 85-208.

Ziemiański, Stanisław. „Kompozytor i nowa pieśń kościelna”. W: Śpiew wiernych w odnowionej liturgii, red. Remigiusz Pośpiech, Piotr Tarlinski. Opole: Wydawnictwo św. Krzyża, I993.

Ziemiański, Stanisław. „Pieśni i piosenki religijne”. W: Polska muzyka religijna-między epokami i kulturami, red. Krystyna Turek, Bogumiła Mika, II4-I30. Katowice: Wydawnictwo Uniwersytetu Śląskiego, 2006. 


\section{RELIGIOUS SONGS AT THE SACROSONG FESTIVAL FROM I969 TO I978}

The 'Sacrosong' Festival of Religious Songs and Hymns (1969-1999) was established at a time when the resolutions of the Second Ecumenical Council of the Vatican were gradually being implemented, including the decision to open the Catholic Church up to new forms of evangelisation. With rock music gaining huge popularity worldwide, it also found enthusiasts among Christian musicians, who employed rock to convey a religious message. The r96os also saw increased interest in the song genre, represented in the field of sacred music by the French Jesuit Aimé Duval, among others.

Despite the difficult social and political situation in communist Poland, the fashion for teenage music and religious songs soon reached that country's youth. The Sacrosong festival was Poland's first platform for the presentation of religious repertoire. It was created not only to support the composition and promotion of new works sung in Polish, but also to involve artists and youngsters in religious life and thereby counteract the atheisation of Polish society.

Over the thirty years of Sacrosong's history as a nationwide festival, its repertoire included songs submitted for the festival's competition, as well as songs, cantatas and oratorios commissioned by the organisers. Musical events were accompanied by theatre shows, exhibitions, poetry evenings, conferences and debates. The competition jury featured celebrities like Wojciech Kilar and Stefan Kisielewski, while the commissioned works were written by such artists as Jerzy Bauer and Marian Sawa (music), Roman Brandstaetter, Ernest Bryll and Revd Jan Twardowski (lyrics).

This article discusses Sacrosong's history and repertoire, as well as its social and cultural role. It also includes reflection on the genre of religious song as the 'chief protagonist' of the festival.

Translated by Tomasz Zymer

Słowa kluczowe / keywords: festiwal / festival, muzyka religijna / sacred music, piosenka religijna / religious song, popularna muzyka chrześcijańska / popular Christian music, PRL / The Polish People’s Republic, Sacrosong, Sobór Watykański II / Second Vatican Council

Barbara Śnieżek - muzykolog, pracownik Zakładu Muzykologii Instytutu Sztuki PAN (Pracownia Etnomuzykologii), współredaktor serii Polska Pieśn i Muzyka Ludowa. Studia i Materiaty. Przygotowuje dysertację doktorską w Szkole Doktorskiej Nauk Humanistycznych UW pod kierunkiem dr. hab. Tomasza Nowaka na temat muzyki pątników z Warszawy na Jasną Górę. Jej główne zainteresowania koncentrują się wokół aktywności muzycznej katolików w Polsce po Soborze Watykańskim II.

barbara.sniezek@ispan.pl 